Maja Račić

Department for primary health care and public health, Faculty of Medicine, University of East Sarajevo, Bosnia and Herzegovina

\section{Family medicine in Republic of Srpska}

\section{Keywords:}

Family medicine, health care system reform, strategy, primary health care

\section{Abstract}

The Family Medicine Development Project in Republic of Srpska was an initiative funded by the Canadian International Development Agency (CIDA). The project introduced family medicine into undergraduate curricula, established three-years long program of residency in family medicine in 1999, created departments of family medicine in both medical schools, helped with the process of establishing a professional association of family physicians, worked with Ministries of health and social welfare to establish supportive policies for these activities, and regularly provided continuing medical education programs for family practitioners during the 13 years of the project. Today, three family medicine teaching centers exist in RS (Primary health care centers Banja Luka, Foča and Bijeljina) where more than 600 physicians were educated either through residency or additional training program in family medicine. Almost 1000 primary care nurses completed additional training. Family medicine centered primary health care reform was a complex innovation, involving organizational, financial, clinical and relational changes. An important factor influencing the adoption of this complex innovation in RS was the perceived benefits of the innovation: benefits which accrue to the users, family physicians, nurses and policy makers. With political commitment, an enabling economic environment and equitable distribution of resources, comprehensive primary health has proved to be a better strategy in achieving the goal of health for all. However, although family medicine passed through long journey from imposition to partnership, there is still large place for the improvement 


\section{Introduction}

\section{The primary health care strategy in Republic of Srpska}

Before 1992, general medicine clinics in Bosnia and Herzegovina $(\mathrm{BiH})$ often functioned essentially as triage centers. Patients were not registered with one GP and appointment system did not exist, so the patients were mainly served by different doctors depending on their current availability. Most conditions were referred to specialists at the health centers or hospitals and treatment was usually based on orders from a specialist. Majority of GPs also did not see their future career in general practice and they were waiting for different residency posts, mainly in internal medicine, gynecology and surgery. Very few physicians pursued residency program in general practice which was completely conducted in inpatient settings, by the specialists of public health or hospital doctors ${ }^{1,2}$.

Beside the level of training of physicians, this situation reflected several factors, restrictive regulations, inadequate equipment, many years of a specialist-based health care system that did not value primary care, and the expectations of patients who had received care in this system ${ }^{1}$.

During the time of Yugoslavia, there had been several, not very successful attempts to reform primary health care. When the civil war finished, the studies and analysis of the World Bank demonstrated widely spread, both absolute and relative poverty in Bosnia and Herzegovina and other countries in the Balkan region. The war had resulted in lower socioeconomic statuses of Bosnia's citizens, raised new health concerns, caused epidemiological changes, and changed the focus of the community. Many primary health care (PHC) physicians emigrated to neighboring counties or to Western Europe and South America, while large percentage of PHC facilities was destroyed. The spread of non-communicable diseases and shortage of health care providers in certain geographic areas, large percentage of uninsured population and the occurrence of violence and crime led to marked health inequity and inequality.

Hereof, with the end to the war in 1995, the RS government, with support from international organizations and multilateral agencies such as the World Bank, began a health reform program to restructure its health system. The reform aimed to develop a new model of PHC centered on family medicine. In 2001, a new model of PHC, piloted in both entities (Republika Srpska [RS] and the Federation of Bosnia and Herzegovina $[\mathrm{FBiH}]$ ) proposed to simultaneously introduce changes in the health systems elements: namely, organizational structure and stewardship, financing, provider payment systems, service provision and resource generation .

The foundation of the primary health care Reform program of the Republic of Srpska was the Declaration adopted at the international conference on PHC, which was held in Alma Ata in September 1978 under the auspices of the World Health Organization and UNICEF. The Declaration of Alma Ata views PHC as follows: "Primary health care is essential health care based on practical, scientifically sound and socially acceptable methods and technology made universally accessible to individuals and families in the community through their full participation and at a cost that the community and country can afford to maintain at every stage of their development in the spirit of self-reliance and self-determination. At the same time, it forms and integral part both of the country's health system, of which it is the central function and main focus, and of the overall social and economic development of the community. It is the first level of contact of individuals, the family and community with the national health system bringing health care as close as possible to where people live and work, and constitutes the first element of a continuing health care process" $3,4,5,6$.

Key health care issues to be considered by the PHC reform program were unequal access to health care, inefficient delivery of health care services, inadequate health care financing, inadequate structure of human resources and ageing population ${ }^{7}$.

Unequal access to health care was caused by a high number of individuals with no health care insurance. The level of direct payment for health services ("out-of pocket" payment) was quite high, thus constituting an additional barrier to the access and aggravating inequality, which rendered individuals more vulnerable to the effects of a disease. A better protection of the most vulnerable groups of the population from health risks, and dealing within equality in access to health care was the key to poverty reduction and enhanced social cohesion ${ }^{1,7}$.

The PHC we inherited focused on disease and therapy, episodic care and passive admission of patients, a higher utilization rate of consultative-specialist and diagnostic services and hospital treatment. The first level of contact of individuals with the health system was fragmented, where the gatekeeping role was limited and insufficient attention was paid to the continuity of health care. At the PHC level, in the majority of health centers, services were delivered according to age, gender or type of disease, by specialized departments or services, which did not constitute the most efficient way of utilization of available resources. Inefficiency of health services delivery was evidenced by health expenditures, where an emphasis remained on the secondary and tertiary health care to the detriment of primary health care.

The health care reform in the RS aimed to: introduce the family medicine model, establish an efficient entry point into the health system, rehabilitate the PHC infrastructure, allow a free choice of a doctor, establish new mechanism for health care resource allocation and introduce new provider payment mechanisms, enhance the organization, planning 
and management of health institutions, develop and implement national health policies, strategies and programs ${ }^{7}$.

\section{The Family Medicine Development Project}

The Family Medicine Development Project in RS was an initiative funded by the Canadian International Development Agency (CIDA) that was sparked by a visit to Queen's University (Kingston, Canada) by the Dean of the Medical School in Sarajevo in 1995. The project involved establishing family medicine teaching centers both medical schools in RS: Foča, and Banja Luka. It introduced family medicine into undergraduate curricula, established three-years long program of residency in family medicine, created departments of family medicine in all medical schools, helped with the process of establishing a professional college of family doctors, worked with ministries of health to establish supportive policies for these activities, and regularly provided continuing medical education programs for family practitioners during the 13 years of the project.

The Family Medicine Development Project in Bosnia and Herzegovina was the contribution of the Canadian Government through the Canadian International Development Agency (CIDA). The primary objective of CIDA's health programming in $\mathrm{BiH}$ was to support health care policy reform by ensuring that the partner country has the capacity to develop and implement health policies that support efficient and effective primary health care. The project's ultimate goal was to establish, with the help of the local physicians and medical faculties, an effective family medicine educational infrastructure that continued after the project finished ${ }^{5,8}$.

The Queen's Family Medicine Program, as well as programs of other international health aid agencies introduced new concepts and approaches to health care that are challenging and at times difficult for individuals to incorporate into their understanding of what it means to be a health care consumer or provider 9 .

\section{Expansion of family medicine}

At operational level, family medicine was established as a medical specialty and introduced into municipality health centers as gatekeepers and providers of PHC services. Autonomous family medicine teams (comprising a family physician and one or two family medicine nurses) were created. At PHC level, users were given the right to choose their family physicians ${ }^{9}$.

Today, there are three family medicine teaching centers in RS (Primary health care centers Banja Luka, Foča and Bijeljina) where more than 600 physicians were educated either through residency or professional additional training in family medicine. Almost 1000 primary care nurses completed additional training over last 13 years. Undergraduate students of medicine and nursing in both medical schools attend compulsory two-semester long courses in family medicine. Since 2005, 226 family medicine clinics have been built or reconstructed.

Budget funding was replaced with a mixed financing system, with the introduction of health insurance to complement budget transfers from the state and local government. Provider payment systems for PHC changed from budgets to simple per capita in order to slow the growth of heath care spending and give the entities impetus to find creative ways to provide services more efficiently. The family medicine model extended the scope of services delivered in the PHC setting by family physicians and family medicine nurses to include health education, promotion, disease prevention interventions, expanded diagnostic and curative services thus enabling the family medicine team to act as a gate keeper while providing more comprehensive and continuous health care services to its registered population ${ }^{10}$

Although many rural PHC centers adopted reform, generally, the success of it was weaker in rural compared to urban settings. Very often, rural PHC centers employed older doctors, specialists with additional training in family medicine who are quite reluctant to the changes or young physicians who are looking for the other post or hospital career. On the other hand, the lack of employment opportunities in rural areas is hindering economic revival and local community is not able to participate in its development.

The study, conducted in 2005-2006, showed that family medicine was seen to be "more rational and cost-effective", introduced "gate keeping" to reduce unnecessary hospitalizations, and increased accessibility to health services which improved equity in the system. Family medicine was seen as a "more human, friendly health care model", with a "holistic approach to the population's health needs", which gave the users simultaneously more "choice" and "responsibility with health decisions". The family orientation of the model allowed "personal problems to be seen in a broader context", "health needs", which gave the users simultaneously more "choice" and "responsibility with health decisions". Perceived benefits for the users included "improved access to the system", "improved doctor-patient relationship" and "an increased individual responsibility for the health professionals towards the user", and "respect for one's time". ${ }^{9}$ Family medicine offers challenges, flexibility, and tremendous diversity. Family physicians provide comprehensive care for patients and their families within the community, with a focus on prevention, management of chronic disease, and coordination of care.

However, family physicians in RS still face some difficulties in their workplace. Many of them see more than 60 patients per day and are overburden by the paperwork activities which account for more than $20 \%$ of the total workday. The hospitalists help hospitals gain tighter control over clini- 
cal management and the use of hospital resources, so, very often patient's care is unnecessary muddled in the transitions between various hospitalists. Proper communication between family physicians and hospital staff is crucial but is frequently lacking in the practice. On the other hand, unstable sources of funding, high percentage of mismatching of income and expenses, as well as a high percentage of the population without insurance are creating additional obstacles to providing good patient care. Although family medicine passed through long journey from imposition to partnership, there is still large place for the improvement and further research on the effectiveness of PHC in RS is needed.

\section{Conclusion}

Family medicine centered primary health care reform was a complex innovation, involving organizational, financial, clinical and relational changes. An important factor influencing the adoption of this complex innovation in RS was the perceived benefits of the innovation: benefits which accrue to the users, family physicians, nurses and policy makers. With political commitment, an enabling economic environment and equitable distribution of resources, comprehensive PHC has proved to be a better strategy in achieving the goal of health for all. 


\section{Марија Рачић}

Катедра за основну здравствену заштиту и јавно здравље

Медицински факултет, Универзитет Источно Сарајево, Босна и Херцеговина

\section{Породична медицина у Републици Српској}

\section{Кључне речи:}

породична медицина, реформа здравственог система, стратегија, примарна здравствена заштита

\section{Сажетак}

Пројект развоја породичне медицине у Републици Српској била је иницијатива финансирана од стране Канадске агенције за међународни развој $(C I D A)$. Кроз пројекат, уведен је предмет Породична медицина на додипломске студије, установљен трогодишњи програм специјализације 1999. године. Основане су Катедре породичне медицине на оба медицинска факултета, помогнут процес оснивања професионалног удружења, успостављена је сарадња са Министарством здравља и социјалне заштите за пружање подршке имплементацији ових активности, те редовно организован Програм континуиране медицинске едукације за љекаре породичне медицине током 13 година. Данас постоје три едукативна центра породичне медицине у Републици Српској (Домови здравља Бања Лука, Фоча и Бијељина), гдје је едукацију завршило више од 600 лекара кроз специјализацију или додатно професионално усавршавање. Готово 1.000 медицинских сестара завршило je додатну професионалну едукацију. Реформа примарне здравствене заштите усмјерена према породичној медицине је била комплексна иновација, укључујући организацијске, финансијске, клиничке промјене и промјене односа у здравственом систему. Важан фактор који је утицао на усвајање ове комплексне иновације у Републици Српској била је перцепција њених предности: користи за кориснике услуга, лекаре породичне медицине, медицинске сестре и креаторе политике. Уз преданост политике, повољно економско окружење и праведну расподелу ресурса, свеобухватна примарна здравствена заштита се показала као боља стратегија у постизању здравља за све. Међутим, иако је породична медицина прошла кроз дуги пут од наметања до партнерства, још увек постоји доста простора за побољшање. 


\section{Literatura}

\section{References}

1. Godwin M. Family Medicine Development Project in Bosnia and Herzegovina. Can Fam Physician. 1999; 45: 1098, 1100, 1103.

2. Šimunović VJ. Health care in Bosnia and Herzegovina before, during, and after 1992-1995 war: a personal testimony. Conflict and Health. 2007; 1:7.

3. WHO. Document WHO/MNC/ OSD/03.01. Geneva: World Health Organization; 2003a. Primary health care: a framework for future strategic directions.

4. WHO. World Health Report 2003 Shaping the future. Geneva: World Health Organization; 2003b.

5. Godwin M, Hodgetts G, Bardon E, Seguin R, Packer D, Geddes J. Primary care in Bosnia and Herzegovina: Health care and health status in general practice ambulatory care centres. Can Fam Physician. 2001; 47: 289-97.
6. Marcos C. The ORIGINS of Primary Health Care and SELECTIVE primary health care. Am J Public Health. 2004; 94 (11): 1864-1874.

7. Ministry of Health and Social Welfare of the Republic of Srpska. The Primary Heath Care Stategy. Banja Luka Ministry of Health and Social Welfare of the Republic of Srpska. 2008.

8. Atun RA, Ibragimov A, Ross G, et al. World Bank Report No. 32354ECA. Human Development Sector Unit, Europe and Central Asia Region. Washington, DC: The World Bank; 2005b. Review of experience of family medicine in Europe and Central Asia. (In five volumes) Volume I: Executive summary.
9. Atun RA, Kyratsis I, Jelic G, RadosMalicbegovic D, Gurol-Urganci I. Diffusion of complex health innovations-implementation of primary care reforms in Bosnia and Herzegovina. Health Policy and Planning. 2007; 22:28-39.

10. Seifert B, Svab I, Madis T, Kersnik J, Windak A, Steflova A, Byma S: Perspectives of family medicine in Central and Eastern Europe. Fam Pract. 2008; 25(2):113-118

Primljen • Received: $\quad$ 17/08/2015 Ispravljen - Corrected: Prihvaćen • Accepted: 01/09/2015 